\title{
Threat of land subsidence in and around Kolkata City and East Kolkata Wetlands, West Bengal, India
}

\author{
P SAHU* and P K SIKDAR \\ Department of Environment Management, Indian Institute of Social Welfare \\ and Business Management, Kolkata 700 073, India. \\ *e-mail: paulamisahu@yahoo.com
}

\begin{abstract}
This paper attempts to estimate the possible rate of land subsidence of Kolkata City including Salt Lake City and the adjoining East Kolkata Wetlands located at the lower part of the deltaic alluvial plain of South Bengal basin. Demand of groundwater for drinking, agricultural and industrial purposes has increased due to rapid urbanization. The subsurface geology consists of Quaternary sediments comprising a succession of clay, silty clay and sand of various grades. Groundwater occurs mostly under confined condition except in those places where the top aquitard has been obliterated due to the scouring action of past channels. Currently, the piezometric head shows a falling trend and it may be accelerated due to further over-withdrawal of groundwater resulting in land subsidence. The estimated mean land subsidence rate is $13.53 \mathrm{~mm} /$ year and for $1 \mathrm{~m}$ drop in the piezometric head, the mean subsidence is $3.28 \mathrm{~cm}$. The surface expression of the estimated land subsidence is however, cryptic because of a time lag between the settlement of the thick low-permeable aquitard at the top and its surface expression. Therefore, groundwater of the cities and wetland areas should be developed cautiously based on the groundwater potential to minimize the threat of land subsidence.
\end{abstract}

\section{Introduction}

Land subsidence is an environmental hazard which is caused by overdraft of groundwater or oil extraction and results in gradual settling or sudden sinking of the earth's surface owing to subsurface movement of the materials of the earth. More than 200 occurrences of land subsidence have been documented throughout the world during the past few years (Ustun et al 2010). Land subsidence associated with groundwater level decline has been recognized as a potential problem in various parts of the world. Important cities such as London, Venice, Mexico, Jakarta, Tokyo, etc., have experienced land subsidence due to over-extraction of groundwater for domestic and industrial purposes (table 1).
Land subsidence occurs when large amounts of groundwater have been withdrawn from certain types of rocks, such as fine-grained sediments. The sediment compacts because the water is partly responsible for holding up the ground. Decline of water table or piezometric surface results in vertical compression of the subsurface materials (Bouwer 1977). Along with vertical compression, lateral compression may also take place due to initiation or acceleration of lateral flow of groundwater. This lateral movement also results in subsidence of the land surface. Any flow or overdraft of groundwater in unconsolidated material should produce some movement of the land surface. This movement is generally small, but may become very significant where subsurface materials

Keywords. Kolkata; East Kolkata Wetlands; groundwater; land subsidence; groundwater potential; sustainable development. 
Table 1. Case histories of land subsidence in other countries.

\begin{tabular}{|c|c|c|c|c|}
\hline Cause & Location & $\begin{array}{c}\text { Maximum } \\
\text { subsidence }(\mathrm{m})\end{array}$ & Period & Source of information \\
\hline \multirow{13}{*}{$\begin{array}{l}\text { Municipal and } \\
\text { industrial } \\
\text { overdraft }\end{array}$} & Su-Xi-Chang, China & 0.018 & 1984-2005 & Zhang et al (2010) \\
\hline & Mashhad, Iran & 0.09 & 1995-2005 & Motagh et al (2007) \\
\hline & Shanghai & 3.00 & $1921-2001$ & Chai et al (2004) \\
\hline & Po Plain, Italy & 0.07 & - & Carminati and Martinelli (2002) \\
\hline & Jakarta, Indonesia & 0.016 & 1991-1997 & Hirose et al (2001) \\
\hline & Hanoi, Vietnam & 0.150 & 1988-1995 & Nguyen and Helm (1995) \\
\hline & Virginia, Atlantic City & 0.004 & $1980-1983$ & Leaky and Martin (1993) \\
\hline & Venice, Italy & 0.15 & $1930-1973$ & Gambolati and Freeze (1973) \\
\hline & Mexico City & 8.00 & $1938-1968$ & Poland (1969) \\
\hline & Tokyo, Osaka & 4.00 & $1928-1943$ & Poland (1969) \\
\hline & Taipei & 1.00 & & Poland (1969) \\
\hline & London & 0.18 & $1865-1931$ & Poland and Davis (1969) \\
\hline & Franklin & 0.01 & $1980-1985$ & Leaky and Martin (1993) \\
\hline \multirow{4}{*}{$\begin{array}{l}\text { Irrigation } \\
\text { overdraft }\end{array}$} & Koyna Closed Basin, Turkey & 0.05 & 2006-2009 & Ustun et al (2010) \\
\hline & San Joaquin Valley, California & 8.50 & - & Lofgren (1969) \\
\hline & Santa Clara Valley & 4.00 & - & Poland (1969) \\
\hline & Eloy Area, Arizona & 2.30 & $1948-1967$ & Schumann and Poland (1969) \\
\hline Oil removal & Wilmington & 9.00 & & Mayuga and Allen (1969) \\
\hline $\begin{array}{l}\text { Brown coal } \\
\text { withdrawal }\end{array}$ & Latrobe Valley, Victoria, Australia & 0.02 & $1970-1977$ & Gloe et al (1973) \\
\hline
\end{tabular}

are thick and/or compressible and the groundwater level declines appreciably (Sikdar et al 1996). Land subsidence may not be noticeable because it can occur over large areas rather than in a small spot. That does not mean that subsidence is not a big event - for example, in the United States, states such as California, Texas and Florida have suffered damage to the tune of hundreds of millions of dollars over the years due to land subsidence. Land subsidence is either individual or a combined effect of inelastic compression of the confining bed and/or elastic compression of the solid matrix of the aquifers. Land subsidence due to groundwater overdraft is essentially irreversible in case of inelastic compression of the overlying confining clay bed. It can be stopped only by halting the decline of groundwater level. However, rebound of the land surface is generally insignificant even if the groundwater levels are restored to the height, prior to subsidence (Bouwer 1977).

The decline of artesian pressure due to withdrawal of water from confined aquifers generally results in decrease in pore-water pressure and consequent increase in effective stress in the subsoil. The distribution of stress at the interface of a confining bed and confined aquifer is as follows:

$$
\sigma=\bar{\sigma}+P
$$

where $\sigma=$ total vertical stress, $\bar{\sigma}=$ effective stress, and $P=$ pore-water pressure.

The increased effective stress is accommodated by the solid matrix of the aquifer which undergo elastic compression as long as artesian pressure continues to decline.

Apart from the elastic compression, inelastic compression of the confining beds of low permeability and silty clay beds included within the confined beds also results in land subsidence due to reduction of artesian pressure by pumping of groundwater. The reduction of artesian pressure in the aquifer creates a hydraulic gradient between the aquifers and the adjacent clay beds resulting in the leakage of the pore water from the adjacent clay bed. This draining out of water reduces pore pressure of the clay bed which then undergoes consolidation. The inelastic compression, leading to vertical shortening of the confining beds or compaction of the clay or silty beds occurring within the confined aquifers, has a greater role in land subsidence than elastic compression. Sikdar et al (1996), Bhattacharyya et al (2004) and Bhattacharyya and Patra (2007) used Dominico's (1972) equation to calculate land subsidence. Now-a-days remote sensing techniques are used to determine land subsidence due to groundwater extraction. For example, C-band ERS-1/2 and ENVISAT radar images have been applied to investigate the urban subsidence due to groundwater abstraction. The Persistent Scatterer InSAR results are interpreted and compared to investigate the effect of groundwater extraction to urban subsidence. The GIS software is used to interpret the Persistent Scatterer InSAR results (Chang et al 2005). Sneed et al (2001) have used global positioning system (GPS) and 
interferometric synthetic aperture radar data to estimate land subsidence due to groundwater abstraction. Hirose et al (2001) have applied digital elevation modelling derived from interferogram using JERS-1/SAR L-band data acquired from 1992 to 1998 to estimate land subsidence. The subsidence data thus acquired was verified by level surveying using GPS. Chatterjee et al (2007) have used differential synthetic aperture radar interferometry (D-InSAR). D-InSAR data processing was carried out using DIAPASON software developed by the French Space Agency (CNES). The problems of identifying and separating the deformation fringes due to temporal decorrelation in the data pairs and atmospheric effects was rectified by filtering the noisy interferograms using an adaptive filter.

Extensive work carried out by Biswas and Saha (1985, 1986, 1992) and Biswas (1990) highlighted the progressive decline of the piezometric head of groundwater in central and south-central parts of Kolkata. Their observation, for the first time, indicated that the progressive decline of the piezometric head of this area may pose problems of land subsidence in future.

Sikdar et al (1996) found that during 19561993, the decline of piezometric level was high in Gobra-Tiljala area with a magnitude of $8.29 \mathrm{~m}$. However, during 1993-1999, it was of the order of around $1 \mathrm{~m}$ as obtained from annual reports of the Central Ground Water Board. In sharp contrast to this, in Kasba-Gariahat-Dhakuria region of south Kolkata, the piezometric drop was found to be $6.82 \mathrm{~m}$ during 1958-1994 (Sikdar et al 1996), whereas the piezometric level changes from $9.07 \mathrm{~m}$ below ground level (bgl) in April 1994 to $15.18 \mathrm{~m}$ bgl in April 1999 in the same region and hence a total drop of $12.93 \mathrm{~m}$ in piezometric level is observed during 1958-1999 in this region of south Kolkata (Bhattacharyya et al 2004; Bhattacharyya and Patra 2007). It should be noted that the premonsoon month April is chosen as the reference month for comparison and this is also in accordance with the recent literature on land subsidence (Agarwal 2002) which states that land subsidence generally occurs in the pre-monsoon period when the water table was the deepest and recharge to groundwater is the least or negligible.

Sikdar et al (1996) reported that due to higher rate of groundwater withdrawal, land subsidence rate in Kolkata ranges from 7.14 to $13.78 \mathrm{~mm} /$ year. The maximum subsidence was estimated in Gobra-Tiljala area in south-central Kolkata, where the subsidence is estimated to be more than $13 \mathrm{~mm} /$ year. The cumulative subsidence between 1956 and 1993 in this area works out to be $0.51 \mathrm{~m}$. The total and the average annual rate of subsidence were also worked out for a period of
42 years from 1958 to 2000 by Bhattacharyya et al (2004). According to this study, apart from excessive subsidence rate of $20.46 \mathrm{~mm} /$ year at Salt Lake area which consists of landfills, the subsidence rate usually varies from 6.52 to $13.0 \mathrm{~mm} /$ year. Land subsidence rate measured in Ultadanga is about $18 \mathrm{~mm} /$ year and its effect is exhibited as prominent cracks found in some buildings in some blocks of Salt Lake (Bhattacharyya and Patra 2007). Chatterjee et al (2007) have identified areas in northern part of Kolkata in and around Machhua Bazar, Calcutta University and Raja Bazar Science College, which had been undergoing subsidence during the period of observation from 1992 to 1998 with an estimated rate of 5 to $6.5 \mathrm{~mm} /$ year. Therefore, it is scary to visualize a scenario of Kolkata City with damaged buildings, subsiding roads and leaning high-rise apartments. Any attempt to estimate the possible land subsidence rate of Kolkata City and EKW should be done against this backdrop.

This paper attempts to assess the possible menace of land subsidence not only of Kolkata and Salt Lake cities - the main business, commercial and financial hub of eastern India and the northeastern states of India, but also of East Kolkata Wetlands $(\mathrm{EKW})$ - a freshwater peri-urban inland wetland ecosystem located at the lower part of the deltaic alluvial plain of South Bengal basin and east of Kolkata City (figure 1). Salt Lake City covering an area of $12.35 \mathrm{~km}^{2}$ was a low-lying saucer shaped basin and a conglomerate of several salt lakes, which were lower than the adjoining drainage channels by an average of $3 \mathrm{~m}$. This swampy area was filled by dredged silt and fine sand from the bed of Hooghly River. The EKW is well known for its resource recovery systems, developed by local people through the ages, using wastewater from the city. EKW was declared as a Ramsar site (No. 1208) on 19 August 2002 (source: www.ramsar.org/brochure.html), therefore attaining an international status. Freshwater wetlands are characterized by a hydrological cycle in which the groundwater within the wetland may be recycled from local and/or distant areas and will comprise varying quantities of water derived from precipitation, surface water bodies and return flow of groundwater used for irrigation in nearby irrigated land. Many wetland hydrology studies have described the wetland water table or developed an annual water budget (Owen 1995; Cooper et al 1998) to establish the link between wetland hydrology and ecology (Drexler et al 1999) or have utilized hydrogeology and isotope composition of groundwater to understand the hydrological processes prevalent in the wetland (Sikdar and Sahu 2009). These studies often fail to represent the threat of land subsidence due to ever-increasing 


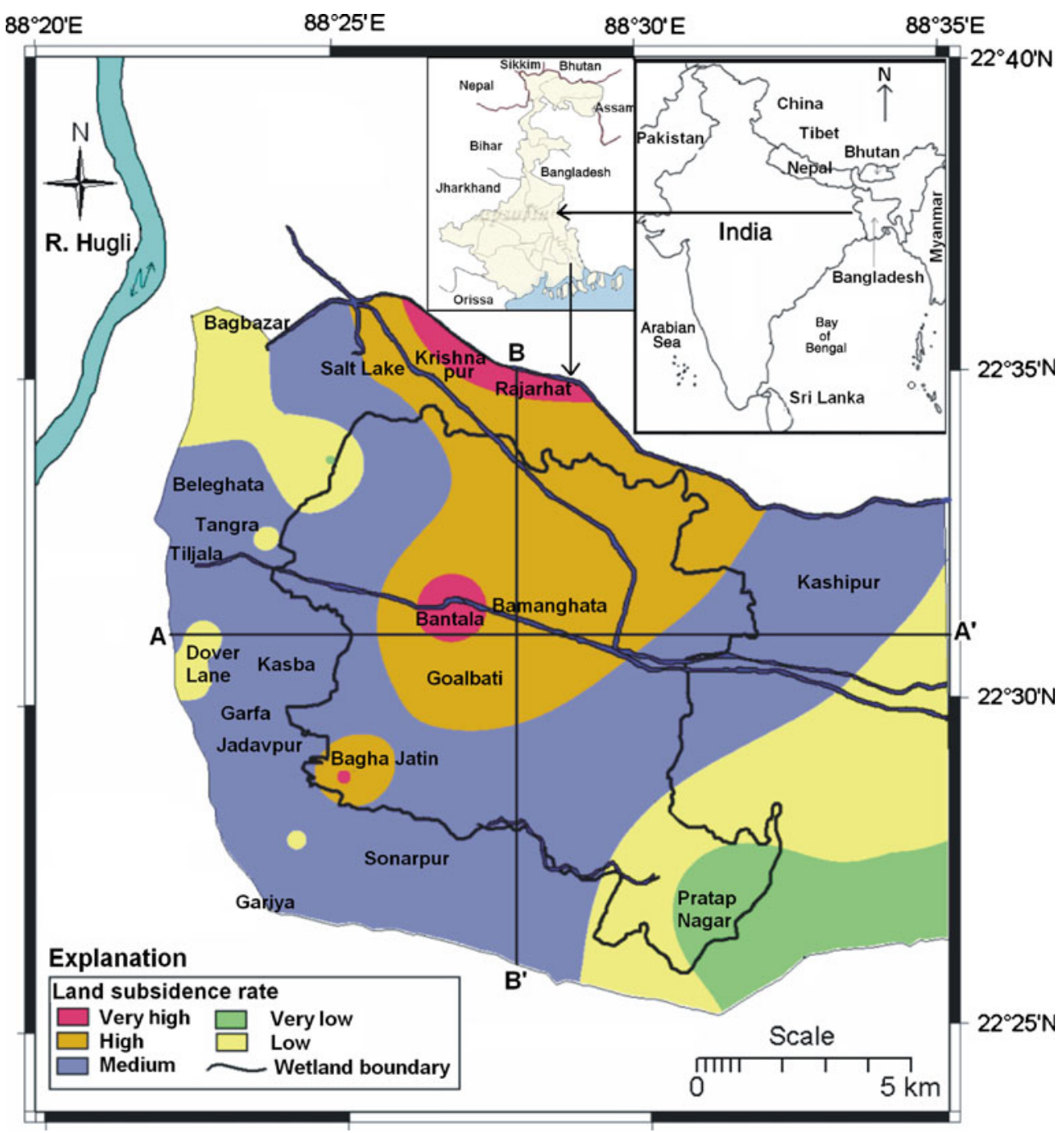

Figure 1. Spatial distribution of calculated land subsidence rate in and around Kolkata, Salt Lake City and EKW.

human-induced pressure on groundwater for drinking, agricultural and industrial purposes.

Abstraction of groundwater from areas prone to land subsidence may cause adverse environmental impact on the wetland's ecosystem. Appropriate site selection for well fields of newly-planned urban centres and industrial estates within close vicinity of any major wetland is a strong pollution preventive measure that ensures environmental soundness of any developmental programme. Therefore, it is imperative to estimate the possible rate of land subsidence and chalk out a sustainable groundwater management plan based on groundwater potential and estimated rate of land subsidence of different areas, especially in a fragile wetland to minimize the adverse environmental impacts of groundwater development.

This study, for the first time, indicates the threat of possible land subsidence due to unrestricted groundwater abstraction in the EKW and also outlines a groundwater management plan for sustain- able development of groundwater in an important fresh water wetland ecosystem of eastern India. This study also compares the rate of land subsidence calculated by different workers for various parts of Kolkata and Salt Lake with this study.

\section{Methodology}

Consolidation of clay as a result of dissipation of pore water pressure is the major reason of land subsidence caused by groundwater pumping. Therefore, land subsidence depends on the subsurface geological profile. The subsurface geology of the area in and around EKW is completely blanketed by the Quaternary fluviatile sediments comprising a succession of silty clay, sand and sand mixed with occasional gravel. In some places along with silty clay, sticky clay is also present at the top of the lithological column. Tertiary clay/silty clay underlies this Quaternary sequence at an average depth of 296 m (Sikdar 2000; Mukherjee et al 2007). This 
formation continues up to a depth of at least $614 \mathrm{~m}$ below the ground surface. Therefore, the Quaternary aquifer of the area is sandwiched between two aquitards made of silty clay/clay and is more or less continuous in nature. A fence diagram (figure 2), correlating the lithologs of favourably located boreholes and vertical electrical sounding data shows a three-dimensional view of the subsurface disposition of the sediments underlying the area. This fence diagram reveals that the top silty clay bed is underlain by a sandy sequence grading from fine to coarse. Thin intercalations of silty clay are also present within the sandy sequence. In the western part of the area, top silty clay bed is very thick, generally $40 \mathrm{~m}$ and above. But the silty clay layer is conspicuously absent at few places in east, north, south and central parts of the area due to the scouring action of earlier channels. In these areas, sands of various grades are observed throughout the entire geological column.

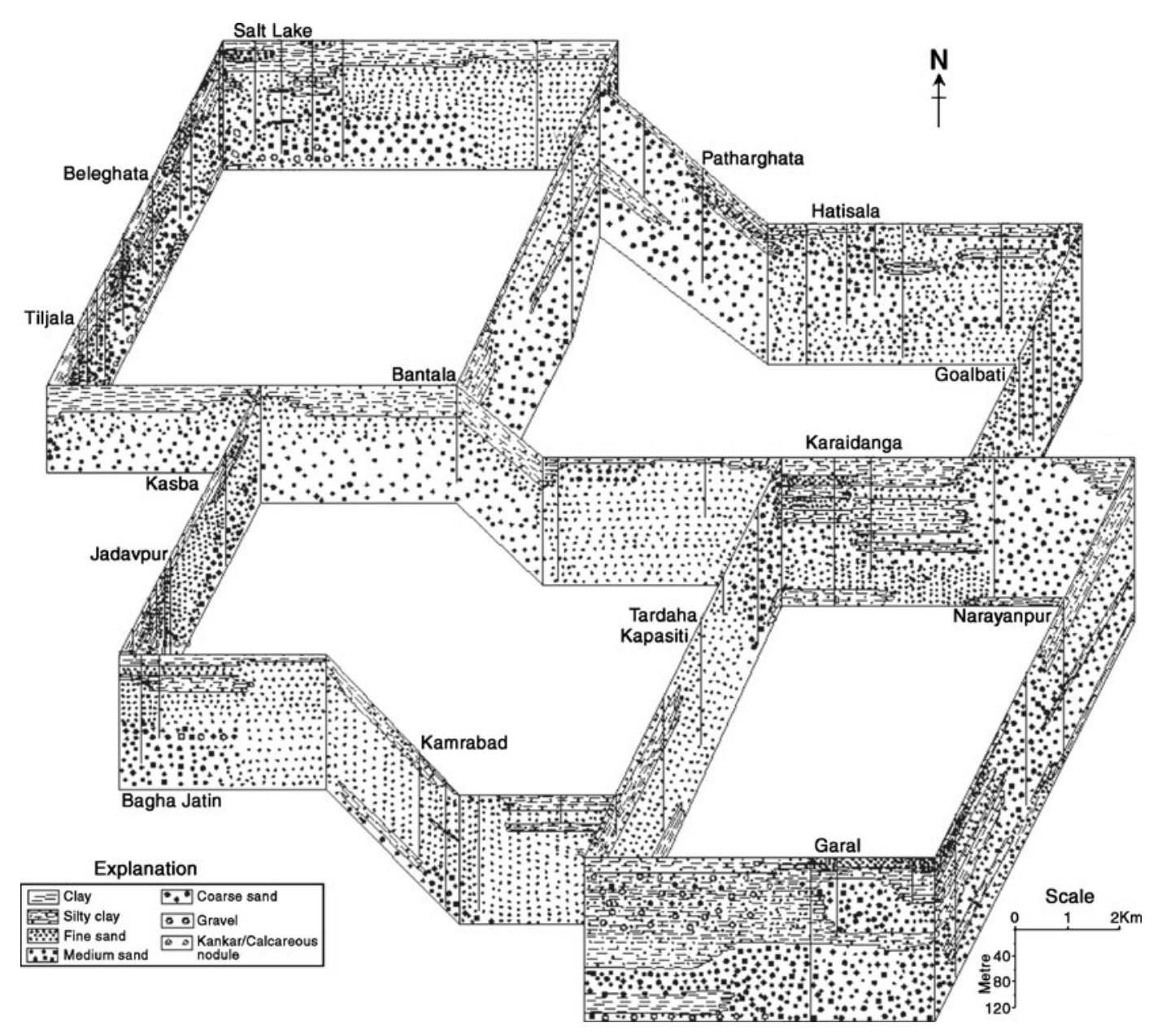

Figure 2. Fence diagram depicting the subsurface geology of the area.

Table 2. Stratification of normal Kolkata deposit (after Dastidar and Ghosh 1967).

\begin{tabular}{llc}
\hline $\begin{array}{l}\text { Depth } \\
\text { range }(\mathrm{m})\end{array}$ & \multicolumn{1}{c}{ Description } & $\begin{array}{c}\text { Coefficient of volume } \\
\text { compressibility, } \\
m_{\mathrm{v}}\left(\mathrm{cm}^{2} / \mathrm{kg}\right)\end{array}$ \\
\hline $0-5$ & Firm grey silty clay & 0.014 \\
$5-15$ & Soft grey clay with wood stumps & 0.04 \\
$15-20$ & Bluish grey clay with kankar & 0.01 \\
$20-25$ & Laminated brown clay, silt & 0.01 \\
$25-30$ & Stiff mottled grey and yellow clay with kankar & 0.01 \\
$>30$ & Mottled silty clay laminated with parting of & - \\
& golden brown silty sand & \\
\hline
\end{tabular}


Table 4. Classification of land subsidence rate.

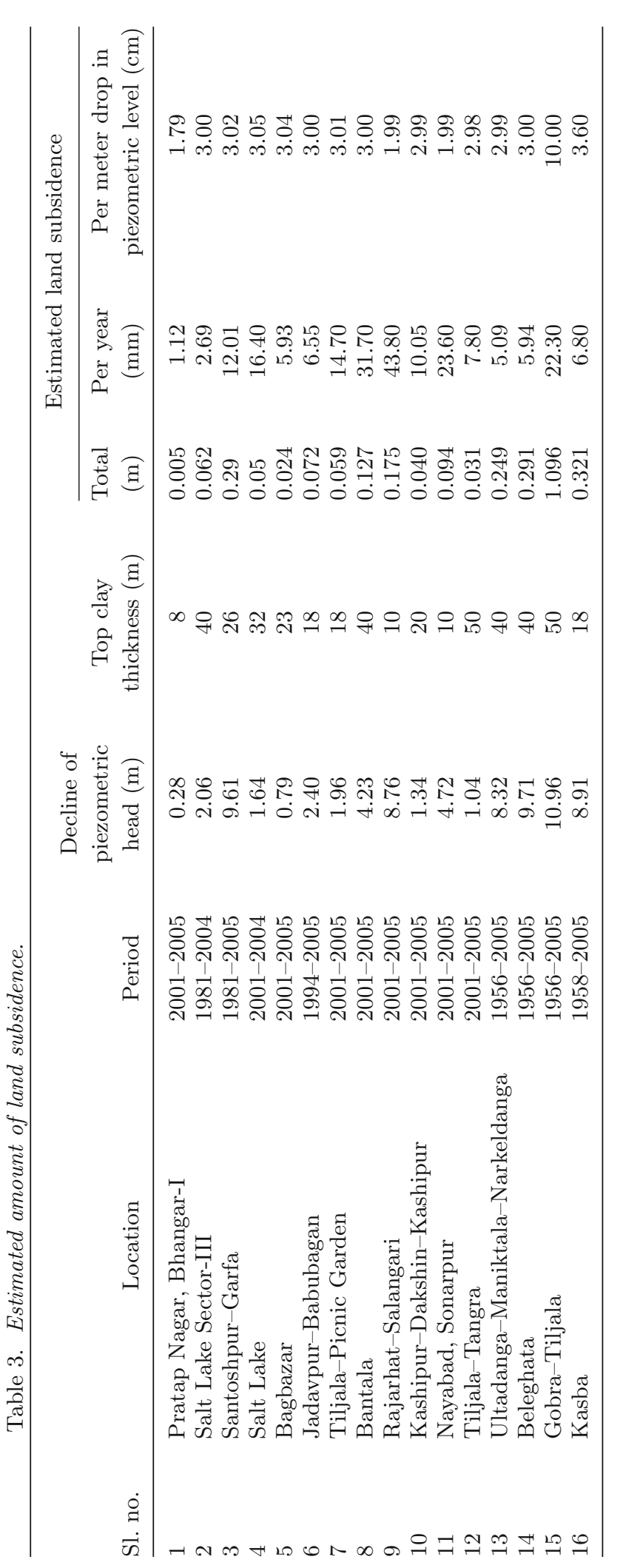

\begin{tabular}{ll}
\hline $\begin{array}{l}\text { Land subsidence } \\
\text { rate }(\mathrm{mm} / \text { year })\end{array}$ & \multicolumn{1}{c}{ Class } \\
\hline$>20$ & Very high \\
$15-20$ & High \\
$10-15$ & Medium \\
$5-10$ & Low \\
$0-5$ & Very low \\
\hline
\end{tabular}

The elastic deformation of the aquifer is insignificant compared to that of the inelastic deformation. This is because, as the piezometric head lowers, the aquifer is recharged with water due to (i) the expansion of water molecules remained in the aquifer, (ii) the compression of aquifer matrix, and (iii) the compression of clay layers above and below the aquifer. Therefore, in this paper, land subsidence only due to inelastic compression of the confining bed has been determined numerically by applying the consolidation theory widely used in soil mechanics.

In this paper, the vertical settlement for onedimensional strain during consolidation has been calculated by using Dominico's (1972) equation which is as follows:

$$
C=m_{\mathrm{v}} \cdot \Delta \sigma \cdot Z \cdot H
$$

where $C=$ amount of land subsidence $(\mathrm{m}), m_{\mathrm{v}}=$ coefficient of volume decrease $\left(\mathrm{cm}^{2} / \mathrm{kg}\right), \Delta \sigma=$ effective stress per metre fall of piezometric head $\left(\mathrm{kg} / \mathrm{cm}^{2}\right), Z=$ drop in piezometric level $(\mathrm{m})$ and $H=$ thickness of the confining bed (m).

The coefficient of volume compressibility $\left(m_{\mathrm{v}}\right)$ of the top aquitard (table 2) used in this study has been taken from the work of Dastidar and Ghosh (1967). The $m_{\mathrm{v}}$ value represents the compressibility of a stratum as expressed by the volumetric strain per unit increase of effective stress. A perusal of table 2 reveals that the top $15 \mathrm{~m}$ of the subsurface formation is relatively soft whereas a low $m_{\mathrm{v}}$ value of clay layer between 15 and $30 \mathrm{~m}$ indicates its comparatively stiff nature. Below $30 \mathrm{~m}$ depth, the compressibility of the layers is even less than $0.01 \mathrm{~cm}^{2} / \mathrm{kg}$ due to increase in overburden pressure. Therefore, volume of pore water squeezed out from the layer decreases with depth. This results in increase in pore water pressure due to increased loading, and results in a time lag between actual settlement of the layer and fall in the piezometric surface. This time lag depends on the hydraulic conductivity and/or thickness of the layer. If the layer is of low hydraulic conductivity and relatively thick, which is the case for Kolkata, it will take some time before this excess pore water is 
squeezed out and hence land subsidence to occur. So clay/other lithotypes present below $30 \mathrm{~m}$, do not play any significant role in land subsidence and therefore, are not taken into account during land subsidence calculation. For Salt Lake City, the $3 \mathrm{~m}$ thick filled material at the upper part of the lithological column was not considered during calculation of land subsidence.

In order to determine the subsidence, past water level data were collected from various published and unpublished papers and reports (Chaterji et al 1964; Biswas and Saha 1986; Sikdar et al 1996; Bhattacharyya et al 2004; Bhattacharyya and Patra 2007). About 85 deep wells were monitored for water level variation during 2003-2005. The monitoring wells of these earlier studies and the current study are different and hence instead of calculating the drop in piezometric head for individual observation wells, it had been calculated sector-wise for a period varying between 1956 and 2005 as available. The entire area has been divided into 16 sectors. The arithmetic mean of the water level of the deep wells of each sector was calculated for a particular year and assigned to the centre of the sector. This value represents the average piezometric head of the sector. In this way, average piezometric heads of all the 16 sectors for the different time periods were assigned. The average fall in the piezometric head was worked out (table 3) and the value was assigned to the centre of each sector. The coefficient of volume compressibility $\left(m_{\mathrm{v}}\right)$ values of Dastidar and Ghosh (1967) for the top $30 \mathrm{~m}$ depth of the stratigraphic column was assigned according to the subsurface lithology available for each sector. The vertical settlement was then calculated by applying the Dominico's (1972) equation. By numerical integration of these vertical settlements, the total settlement of the ground in various parts of the area was estimated (table 3 ).

\section{Results and discussion}

The estimated land subsidence varies between 1.12 and $43.8 \mathrm{~mm} /$ year (table 3 ) with a mean of $13.53 \mathrm{~mm} /$ year. The estimated land subsidence for $1 \mathrm{~m}$ drop in the piezometric head varies from 1.79 to $10 \mathrm{~cm}$ with an average of $3.28 \mathrm{~cm}$. Categorization of the rate of land subsidence is given in table 4 . The spatial distribution of the calculated land subsidence is depicted in figure 1. A perusal of the map indicates that maximum part of the area falls under the category of medium land subsidence rate.

A comparative study of land subsidence rate for a given period and their respective average drop of piezometric head in parts of Kolkata and surrounding area calculated by the present author and other workers is summarized in table 5 .

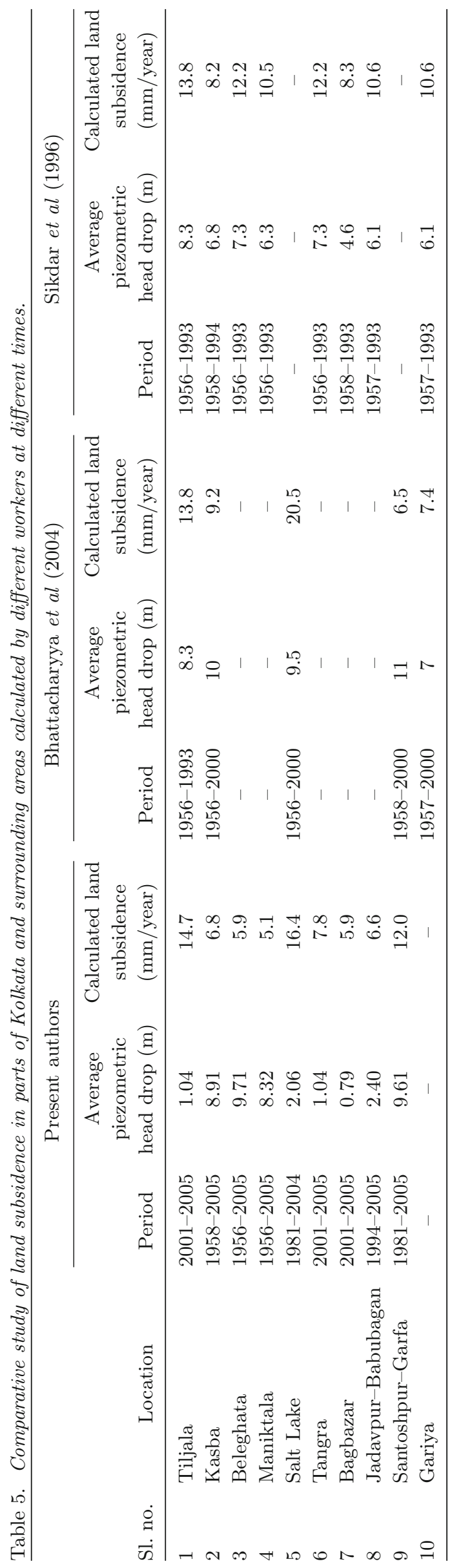




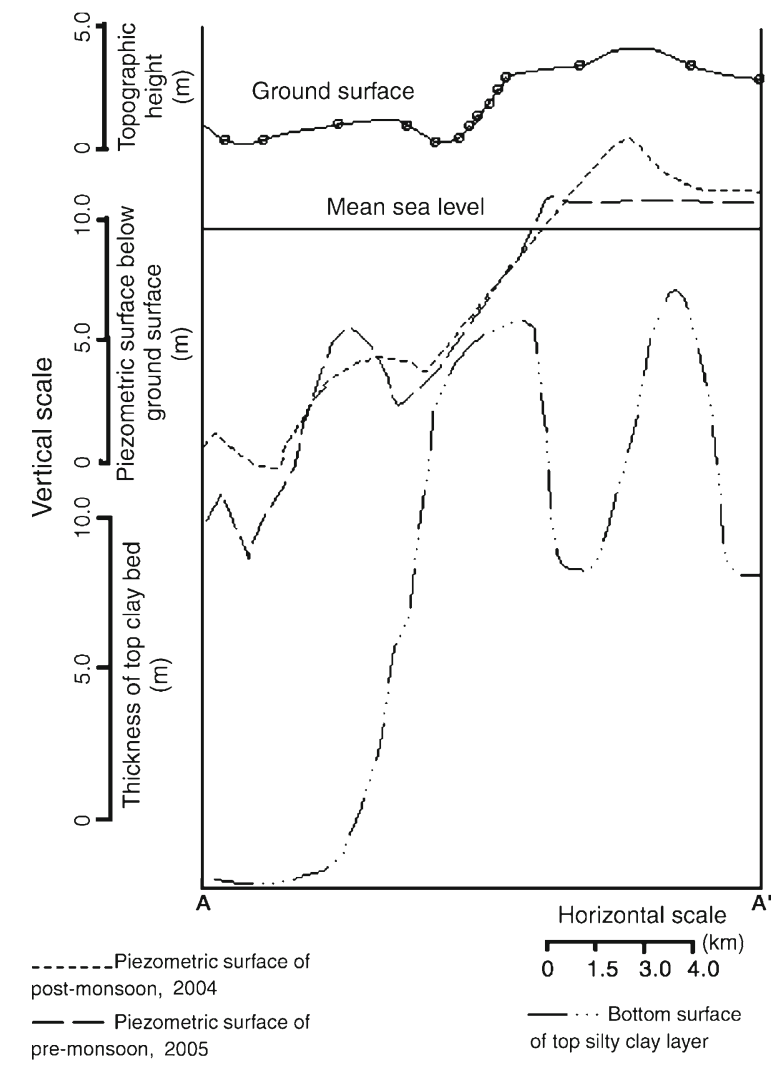

Figure 3. Cross-section along $\mathrm{AA}^{\prime}$ showing the position of piezometric surface with respect to ground surface and bottom surface of top silty clay layer.

The different values of land subsidence estimates (table 5) by various authors are due to supply of treated surface water in various parts of the city by the government resulting in lesser groundwater pumping. Therefore, the piezometric head has recovered in majority of the areas, and land subsidence has slowed down. In areas such as Tiljala and Santoshpur-Garfa, land subsidence has increased because of the construction of new high-rise buildings with one or more tubewells fitted with medium to heavy-duty motor pumps.

To understand the interrelation between the depths of the piezometric surface in different seasons and base of the top silty clay bed, two crosssections $\mathrm{A}-\mathrm{A}^{\prime}$ and $\mathrm{B}-\mathrm{B}^{\prime}$ (figure 1 ) are drawn. These sections, $\mathrm{A}-\mathrm{A}^{\prime}$ along the east-west and $\mathrm{B}^{-\mathrm{B}^{\prime}}$ along the north-south, are shown in figures 3 and 4 , respectively.

These sections reveal that the groundwater occurs in a confined condition with the piezometric head above the base of the top confining clay bed. In areas such as Bantala and Bamanghata (figure 1), the piezometric head is only 0.6 to $1.0 \mathrm{~m}$ (figure 3 ), and $1.6 \mathrm{~m}$ (figure 4 ) above the base of the confining bed, respectively. Therefore, groundwater abstraction in these areas should be restricted. Excessive groundwater withdrawal from

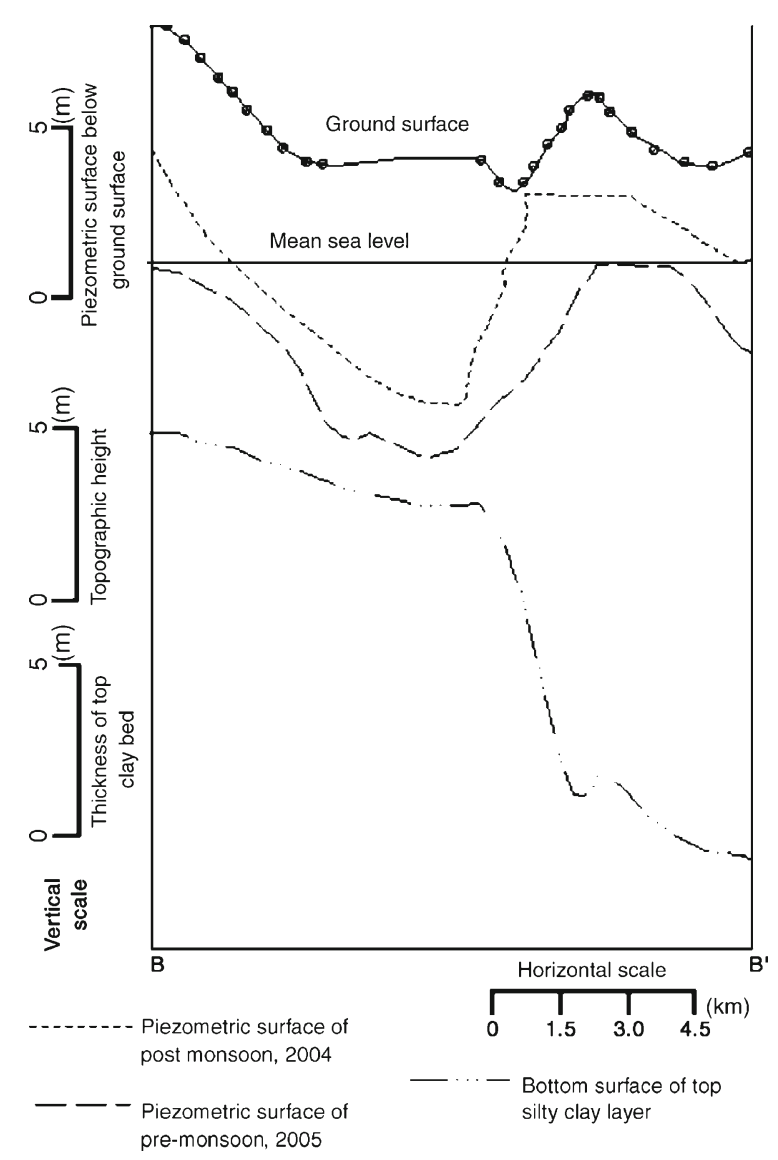

Figure 4. Cross-section along $\mathrm{BB}^{\prime}$ showing the position of piezometric surface with respect to ground and bottom surfaces of the top silty clay layer.

these parts of the aquifer will result in further drop of the piezometric head. The piezometric head in such a condition may ultimately fall below the base of the confining bed, which will lead to change in the aquifer condition from a confined system to an unconfined one. This will result in loss of water from the overlying aquitard into the underlying aquifer. If this water contains toxic material, then the underlying fresh water aquifer may get polluted. Again loss of water from the aquitard will result in volumetric compression of the aquitard, which will be manifested at the surface in the form of land subsidence.

From the above discussion, it is imperative that groundwater of the cities and wetland areas should be developed cautiously to avoid the threat of land subsidence. Therefore, groundwater development should be carried out based on the groundwater potential and the perceived threat of land subsidence in the area. Sahu and Sikdar (2009) have categorized the area into five groundwater potential zones namely very poor, poor, medium, good and excellent (figure 5). Detailed study groundwater potential zones of Kolkata including Salt 


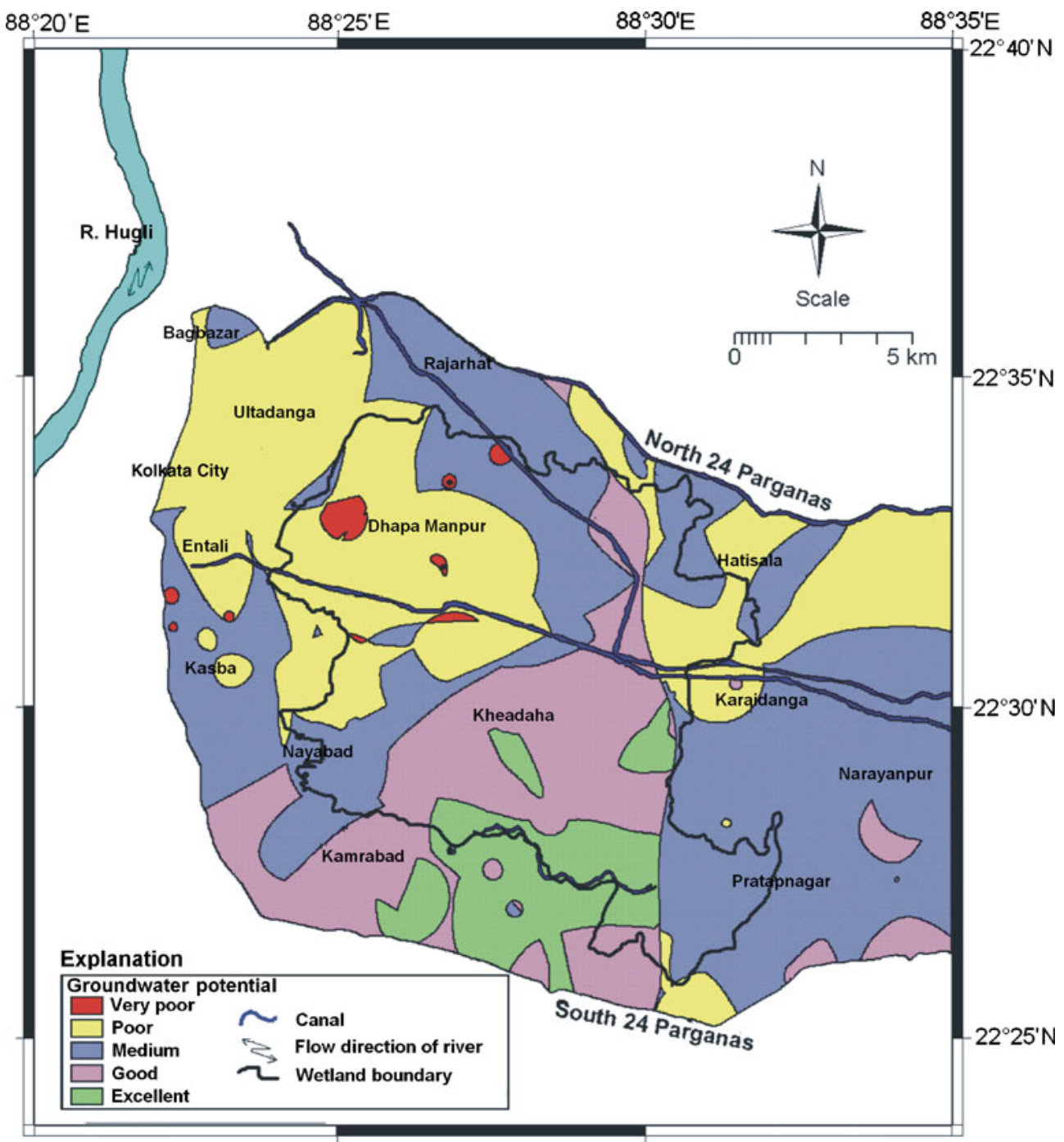

Figure 5. Spatial distribution of groundwater potential of the area.

Lake and EKW is described in Sahu and Sikdar (2009).

Land subsidence can have several negative economic and social implications such as changes in groundwater and surface water flow patterns, restrictions on pumping in land subsidence-prone areas, localized flooding, failure of well casings as well as shearing of structures. To minimize such environmental effects, groundwater management should be considered in subsidence-prone areas (Don et al 2006). To chalk out appropriate groundwater management plans for sustainable development of groundwater, a cross-operation between spatial distribution of groundwater potential and land subsidence rate has been carried out using the GIS software ILWIS 3.3 Academic Version. The resultant cross map (figure 6) of the entire area has been divided into three classes and the management options recommended for each of the classes are shown in table 6 .

\section{Conclusion}

The results described in this paper reveal that the estimated land subsidence rate of the area ranges between 1.1 and $43.8 \mathrm{~mm} /$ year with an average of $13.5 \mathrm{~mm} /$ year. Visible evidences of land subsidence have not yet been recorded because of the presence of a thick layer of very low permeable material at the top of the geological column. The surface expression of the estimated land subsidence is however, cryptic because of a time lag between the settlement of clay/silty clay and its surface expression. For example, although in Kolkata no surface expression of land subsidence is reported, the effect of land subsidence is exhibited as prominent cracks have been found in a few buildings in some blocks of Salt Lake (Bhattacharyya and Patra 2007). The calculated land subsidence however needs ground verification by recalibrating the reduced levels of the existing benchmarks. Again, 


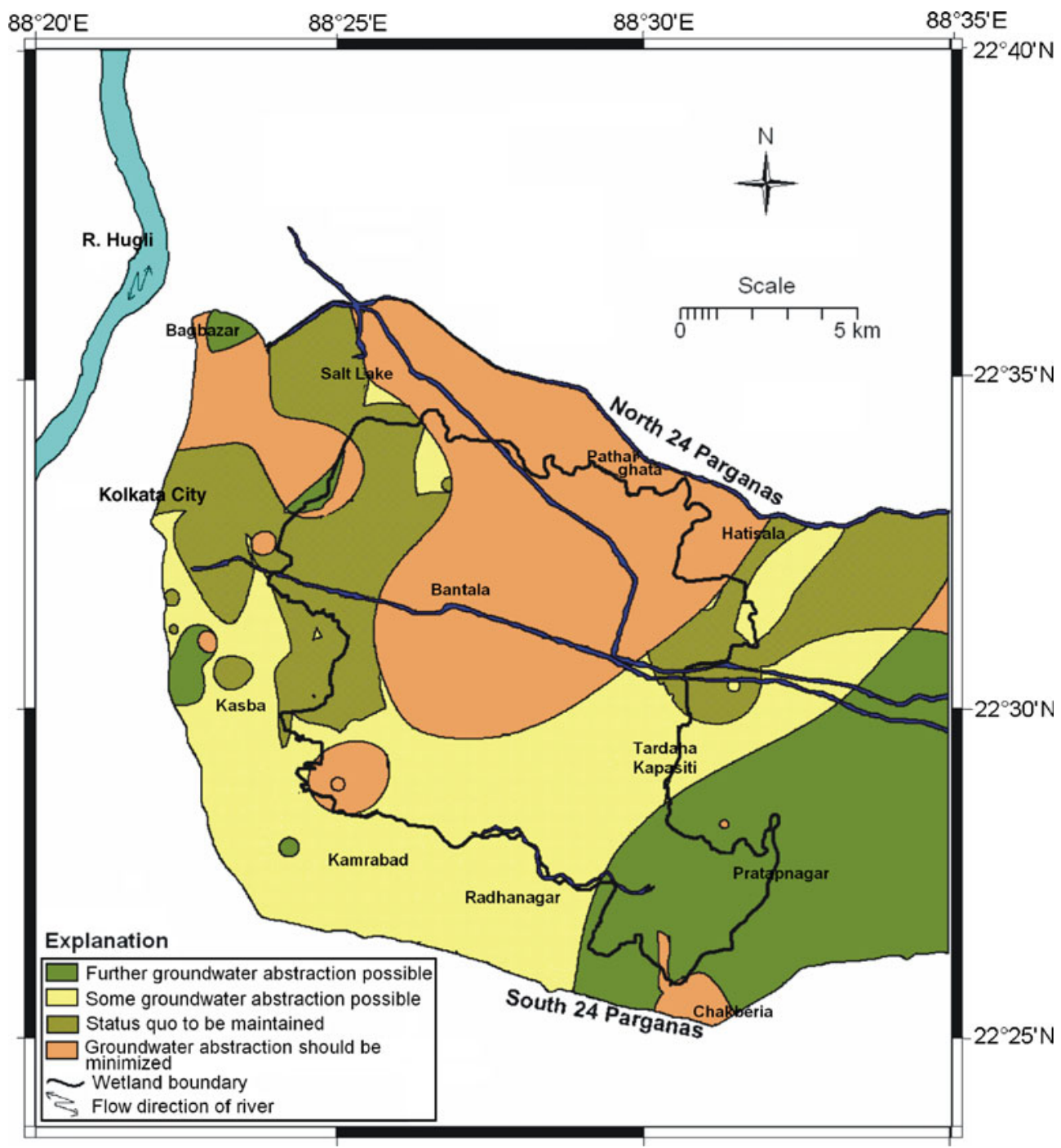

Figure 6. Cross map between land subsidence and quality-based groundwater potential of the area.

Table 6. Management plans for zones with different land subsidence rates and different groundwater potential.

\begin{tabular}{|c|c|c|c|}
\hline \multirow{2}{*}{$\begin{array}{l}\text { Ground water } \\
\text { potential }\end{array}$} & \multicolumn{3}{|c|}{ Land subsidence } \\
\hline & Very high to high & Medium & Poor to very poor \\
\hline $\begin{array}{l}\text { Excellent } \\
\text { to good }\end{array}$ & $\begin{array}{l}\text { Groundwater abstraction should be } \\
\text { minimized and treated surface water } \\
\text { supply system to be introduced; } \\
\text { introduction of roof-top } \\
\text { rainwater harvesting. }\end{array}$ & $\begin{array}{l}\text { Some ground water } \\
\text { abstraction possible }\end{array}$ & $\begin{array}{l}\text { Further ground water } \\
\text { abstraction possible }\end{array}$ \\
\hline Medium & $\begin{array}{l}\text { Groundwater abstraction should be } \\
\text { minimized and treated surface water } \\
\text { supply system to be introduced; } \\
\text { introduction of roof top rainwater } \\
\text { harvesting and artificial recharge. }\end{array}$ & $\begin{array}{l}\text { Some ground water } \\
\text { abstraction possible }\end{array}$ & $\begin{array}{l}\text { Further ground water } \\
\text { abstraction possible }\end{array}$ \\
\hline $\begin{array}{l}\text { Poor to } \\
\text { very poor }\end{array}$ & $\begin{array}{l}\text { Groundwater abstraction should be } \\
\text { minimized and treated surface water } \\
\text { supply system to be introduced; } \\
\text { introduction of roof top } \\
\text { rainwater harvesting and } \\
\text { artificial recharge. }\end{array}$ & $\begin{array}{l}\text { Status quo to } \\
\text { be maintained }\end{array}$ & $\begin{array}{l}\text { Groundwater abstraction } \\
\text { should be minimized and } \\
\text { treated surface water supply } \\
\text { system to be introduced; } \\
\text { introduction of roof top } \\
\text { rainwater harvesting. }\end{array}$ \\
\hline
\end{tabular}


to measure the actual compaction of sediments, compaction recorders or extensometers should be installed in areas of heavy pumping. A piezometer should be installed close to each extensometer to record the variation in depth of the piezometric surface. This in turn would help to understand the field relationship between the head decline and land subsidence (Sikdar et al 1996). Development of groundwater should be done cautiously to avoid the threat of land subsidence. Groundwater development should be carried out based on the groundwater potential and the perceived threat of land subsidence in the area.

\section{Acknowledgements}

The authors convey their thanks to the Director, Indian Institute of Social Welfare and Business Management for his help and encouragement during the research work. PS is thankful to Council of Scientific and Industrial Research (CSIR), India for the financial assistance.

\section{References}

Agarwal C S 2002 Geomorphological study for land subsidence in a part of District Farrukhabad; Hydrol. J. 25(1) 61-68.

Bhattacharyya A K and Patra M N 2007 Land subsidence in Salt Lake City and adjoining areas of Kolkata; ICFAI J. Earth Sci. 1(2) 75-86.

Bhattacharyya A K, Basak S and Patra M N 2004 Land subsidence in Calcutta under the effect of hydrogeological conditions and over-extraction of groundwater; EJGE 9 $1-16$.

Biswas A B 1990 Geology and groundwater resources of Calcutta Metropolitan District; Geogr. Rev. India 52(3) $10-24$.

Biswas A B and Saha A K 1985 Environmental hazards of the recession of piezometric surface of the groundwater under Calcutta; Proc. Indian Natl. Sci. Acad. 51A(3) 610-621.

Biswas A B and Saha A K 1986 Groundwater condition of Calcutta Metropolitan Area; Unpublished Project Report, C.S.M.E.

Biswas A B and Saha A K 1992 Water supply problems of the Calcutta Metropolitan Districts; Proceedings of Seminar on Calcutta Water Supply - Techno Economic Options.

Bouwer H 1977 Land subsidence and cracking due to groundwater depletion; Groundwater 15(5) 358-364.

Carminati E and Martinelli G 2002 Subsidence rates in the Po Plain, northern Italy: The relative impact of natural and anthropogenic causation; Eng. Geol. 66 $241-255$.

Chai J C, Shen S L, Zhu H H and Zhang X L 2004 Land subsidence due to groundwater drawdown in Shanghai; Geotechnique 54 143-147.

Chang H C, Ge L and Rizos C 2005 Radar interferometry for monitoring land subsidence due to underground water extraction; Spatial Sciences Conference, Melbourne, Australia, 736-743, CD-ROM procs, 12-16 September 2005.
Chaterji G C, Biswas A B, Basu S and Niyogi B N 1964 Geology and groundwater resources of the Greater Calcutta Metropolitan Area, West Bengal; Bull. Geol. Surv. India Sr. B21 1-150.

Chatterjee R S, Roy P S, Dadhwal V K, Lakhera R C, Quang T X and Saha R 2007 Assessment of land subsidence phenomenon in Kolkata City, India using satellite-based D-InSAR technique; Curr. Sci. 93(1) 85-90.

Cooper D J, MacDonald L H, Wenger S K and Woods S W 1998 Hydrologic restoration of a fen in Rocky Mountain National Park, Colorado, USA; Wetlands 18 335-345.

Dastidar A G and Ghosh P K 1967 A study of subsoil conditions of Calcutta; J. Inst. Eng. (India) 48(3) 692-714.

Dominico P A 1972 Concepts and Models in Groundwater Hydrology (New York: McGraw Hill Book Co.).

Don N C, Hang N T M, Araki H, Yamanishi H and Koga K 2006 Groundwater resources management under environmental constraints in Shiroishi of Saga plain, Japan; Environ. Geol. 49 601-609.

Drexler J Z, Bedford B L, DeGaetano A T and Seigal D I 1999 Quantification of water budget and nutrient loading in a small peatland; J. Amer. Water Resour. Assoc. 35 753-769.

Gambolati G and Freeze R A 1973 Mathematical simulation of the subsidence of Venice; Water Resour. Res. 9(3) $721-733$.

Gloe C S, James J P and McKenzie R J 1973 Earth movements resulting from brown coal open cut mining Latrobe Valley, Victoria. Subsidence in Mines; 4th Annual Symposium, Illawarra Branch, Australian Institute of Mineral and Metallurgy, 8 1-9.

Hirose K, Maruyama Y, Murdohardono D, Effendi A and Abidin H Z 2001 Land subsidence detection using JERS1 SAR Interferometry, Paper presented at the 22nd Asian Conference on Remote Sensing, 5-9 November 2001, Singapore.

Leaky P P and Martin M 1993 Geohydrology and simulation of groundwater flow in the Northern Atlantic Coastal Plain aquifer system, USGS Professional Paper, 1404-K, pp. 1-81.

Lofgren B E 1969 Field measurement of aquifer-system compaction, San Joaquin Valley, California, USA, \& Land subsidence; Proceedings of the First International Symposium, International Association of Hydrological Sciences, Tokyo, Japan, pp. 272-284.

Mayuga M N and Allen D R 1969 Subsidence in the Wilmington Oil Field, Long Beach, California, USA; IAHS-AISH Publication, 88p.

Motagh M, Djamour Y, Walter T R, Wetzel H U, Zschau J and Arabi S 2007 Land subsidence in Mashhad Valley, northest Iran: Results from InSAR, levelling and GPS; Geophys. J. Int. 168 518-526.

Mukherjee A, Fryar A E and Howell P D 2007 Regional hydrostratigraphy and groundwater flow modeling in the arsenic-affected areas of the western Bengal basin, West Bengal, India; Hydrogeol. J. 15 1397-1418.

Nguyen T Q and Helm D C 1995 Land subsidence due to groundwater withdrawal in Hanoi, Vietnam; Fifth International Symposium on Land Subsidence, The Hague, 1AHS Publ. No. 234, 55-60.

Owen C R 1995 Water budget and flow pattern in an urban wetland; J. Hydrol. 169 171-187.

Poland J F 1969 Land subsidence and aquifer-system compaction, Santa Clara Valley, California, USA; In: Land Subsidence (ed.) Tison L J, vol. 2, International Association of Science Hydrology Publication 88 285-292.

Poland J F and Davis G H 1969 Land subsidence due to withdrawal of fluids; In: Reviews in Engineering Geology, 
(eds) Varnes D J and Kiersch G A, Geol. Soc. Am. 2 187-269.

Sahu P and Sikdar P K 2009 Groundwater potential zoning of a peri-urban wetland of south Bengal Basin, India; Environ. Monit. Assess. 174 119-134, doi: 10.1007/ s10661-010-1443-2.

Schumann H H and Poland J F 1969 Land subsidence, earth fissures and groundwater withdrawal in South Central Arizona, U.S.A.; International Symposium on Subsidence, Tokyo, 295-302.

Sikdar P K 2000 Geology of the Quaternary aquifers of the twin City of Calcutta-Howrah; J. Geol. Soc. India 56(8) 169-186.

Sikdar P K, Biswas A B and Saha A K 1996 A study on the possible land subsidence in Calcutta and Howrah cities due to groundwater overdraft; Indian J. Geol. 68(3) 193-200.
Sikdar P K and Sahu P 2009 Understanding wetland subsurface hydrology using geologic and isotopic signatures; Hydrol. Earth Syst. Sci. 13 1313-1323.

Sneed M, Marti E, Galloway Ikehara D L and Amelung F 2001 Detection and measurement of land subsidence using global positioning system and interferometric synthetic aperture radar, Coachella Valley, California; 1996-98.

Ustun A, Tusat E and Yalvac S 2010 Preliminary results of land subsidence monitoring project in Konya Closed Basin between 2006-2009 by means of GNSS observations; Nat. Hazards Earth Syst. Sci. 10 11511157.

Zhang Y, Xue Y Q, Wu J C, Shi X Q and Yu J 2010 Excessive groundwater withdrawal and resultant land subsidence in the Su-Xi-Chang area, China; Environ. Earth Sci. 61 1135-1143. 